\title{
Mengembangkan Moderasi Pendidikan Islam Melalui Peran Pengelolaan Pondok Pesantren
}

\author{
Sumarto', Emmi Kholilah Harahap ${ }^{2}$ \\ sumarto.manajemeno@gmail.com \\ Pascasarjana IAIN Curup, STAI Ma'arif Jambi
}

\begin{abstract}
Abstrak
Moderatisme, ummat Islam dipandang sebagai ummatanwasathan, sebagai ummat yang cinta perdamaian dan anti kekerasan.Dengan wajah senyum tersebut, Ummat Islam tampil sebagai ummat yang mengutamakan misi perdamaian, kekerasan dan toleransi.Misi ini ditujukkan ketika Islam disebarkan keseluruh pelosok dunia. Salah satu lembaga pendidikan Islam yang mengembangkan Islam Moderat adalah Pondok Pesantren, Lembaga pendidikan Islam yang banyak berkontribusi untuk kemerdekaan bangsa, kemajuan pendidikan bangsa dan memberikan dakwah untuk keselamatan di dunia dan akhirat. Sehingga sangat jelas bahwa peran pengelolaan pondok pesantren menolak segala bentuk tindakan radikalisme dan ekstrimisme, aksi terror yang merusak sendi-sendi kerukunan dan kedamaian ummat manusia. Dalam tulisan ini, penulis ingin menjelaskan tentang bagaimana peran pondok pesantren dalam kegiatan sehari-hari di pondok pesantren, untuk mengembangkan Islam yang moderat, mulai proses belajar mengajar di kelas, kegiatan ekstra kurikuler dan pengabdian di lingkungan masyarakat sekitar pondok pesantren. Karena pondok pesantren adalah lembaga yang menggaungkan dan mengajak masyarakat dengan Islam yang moderat Islam rahmatallil'alamin.
\end{abstract}

Kata Kunci: Moderasi Pendidikan Islam, Pondok Pesantren

\section{A. Pendahuluan}

Pentingnya penanaman nilai dalam proses pendidikan Islam ditujukan agarpeserta didik memiliki way of life (pandangan hidup) dalam menjalani kehidupannya Dalam konteks ini, pendidikan Islam dapat berwujud segenap kegiatan yang dilakukan seseorang atau suatu lembaga untuk membantu seorang atau sekelompok peserta anak didik dalam menanamkan dan/atau menumbuhkembangkan ajaran Islam dan nilainilainya.

Salah satu nilai ajaran Islam adalah moderatisme yang mengajarkan posisi tengah, tidak fanatik/berlebihan dalam berpikir dan bertindak.Ajaran ini menekankan pentingya keseimbangan, tidak berdiri pada kutub ekstrim, baik dalam pemahaman dan pengamalan Islam.Moderatisme dalam Islam juga mengajarkan inklusifme, persaudaraan, toleransi, perdamaian dan Islam sebagai rahmatan lil'alamin.

Dengan moderatisme, ummat Islam dipandang sebagai ummatanwasathan, sebagai ummat yang cinta perdamaian dan anti kekerasan.Dengan wajah senyum tersebut, Ummat Islam tampil sebagai

\footnotetext{
${ }^{1}$ Dosen Pascasarjana IAIN Curup.

${ }^{2}$ Dosen Sekolah Tinggi Agama Islam Ma'arif Jambi.
} 
ummat yang mengutamakan misi perdamaian, kekerasan dan toleransi.Misi ini ditujukkan ketika Islam disebarkan keseluruh pelosok dunia.Perang dalam Islam hanya diperbolehka ketika ummat Islam dalam keadaan terdesak dan mempertahakan diri. Para Pendakwah menyebarkan Islam di Indonesia - khususnya ke Pulau Jawa (wali songo) menyebarkan Islam dengan menggunakan media budaya, pendidikan.Bahkan mereka melakuka akulturasi dan kontekstualisasi ajaran Islam dengan budaya local. ${ }^{3}$

Pada proses pembelajaran, penanaman moderatisme dilakukan dalam bidang studi yang tergabung pada ilmu-ilmu keislamaan, yaitu: alQur'an, Hadits, Sejarah Kebudayaan Islam, Aqidah dan akhlak. Pada pembelajaran di atas, para ustad menekankan pada karakteristik ajaran Islam yang mengajarkan nilai-nilai persatuan, tolong-menolong dalam kebaikan, kerja sama, toleransi. Penanaman nilai-nilai tersebut dilakukan agar terjalin hubungan yang harmonis antar santri dan ketika merekalulus dari pesantren, mereka menjadi perekat ummat Islam di tengah keragaman ummat.

Demikian juga, pembelajaran nilai-nilai moderat dilakukan dalam proses pembelajaran dengan menekankan pentingnya toleransi kepadakeberagaman agama, madzhab dan paham. Penanaman sikap tersebutditampilkan dalam beberapa dengan menanamkan sikap dan prilakutoleransi. Penanaman sikap tersebut, misalnya dilakukan meluluipembelajaran pada bidang edukasi hadith.

Dalam Bidang edukasi hadith terdapat materi-materi pembelajaran yang menanamka nilai-nilai mederatisme. Upaya ini dilakukan untuk menanamkan sikap toleran dan inklusivisme antara santri yang berbeda kultur dan tradisi. Sebagai teladan dalam konteks ini dapat dikemukakan riwayat dalam Sirah Ibn Ishâq diceritakan bahwa Nabi mencegah tamunya kaum Nasrani Najran -yang dipimpin Abd al-Masîh al-Ayhâm dan Abû Harits ibn al-Qamâa-untuk mencari tempat ibadah di luar masjid Nabawi untuk melaksanakan kebaktian, dan mempersilahkan merekamelakukan kebaktian di masjid Nabawi. Nabi juga bersabdabahwa barang siapa yang menyakiti minoritas (non muslim), maka ia telah menyakiti Nabi. Al-Qur'ân pun menegaskan bahwa Islam mengakui eksistensi agama-agama lain dan tidak menolak nilai-nilai ajarannya. ${ }^{4}$

Penanaman nilai-nilai moderatisme juga dilakukan dalam kegiatankegiatandi luar proses pembelajaran (ekstra kurikuler). Kegiatan ektrakulikuler yang menekankan nilai-nilai moderasi adalah kegiatan Pramuka. Para pembina kegiatan itu menamkan nilai toleransi atasperbedaan, kesetiakawanan, solidaritas, kerja sama, persatuan, kekompakan dan kebersamaan antara santri yang mengikuti kegiatan ini.

\footnotetext{
${ }^{3}$ Mohammad Muchlis Solichin, "PENDIDIKAN ISLAM MODERAT DALAM BINGKAI KEARIFAN LOKAL," Jurnal MUDARRISUNA: Media Kajian Pendidikan Agama Islam 8, no. 1 (20 Juli 2018): 174-94, https://doi.org/10.22373/jm.v8i1.2950.

${ }^{4}$ Solichin.
} 


\section{B. Pembahasan}

\section{Moderasi Pendidikan Islam}

Adapun term moderat memiliki dua makna, yaitu: (1) selalu menghindarkan perilaku atau pengungkapan yangekstrem; dan (2) berkecenderungan ke arah dimensi atau jalantengah.Oleh karena itu, paham moderat berarti paham yangtidak ekstrem, dalam arti selalu cenderung pada jalan tengah.Muchlis M.Hanafi memaknai moderat (al-wasath) sebagaimetode berpikir, berinteraksi dan berperilaku secara tawazun(seimbang) dalam menyikapi dua keadaan, sehinggaditemukan sikap yang sesuai dengan prinsip-prinsip Islamdan tradisi masyarakat, yaitu seimbang dalam akidah, ibadahdan akhlak.

Masdar Hilmy menyebutkan term moderat merupakan konsep yang sulit didefinisikan.Penggunaannyamerujuk pada al-tawassuth (moderasi), al-qisth (keadilan),al-tawâzun (keseimbangan), al-i,tidâl (kerukunan) dansemacamnya.Namun demikian, dalam konteks Indonesiaterdapat beberapa karakteristik moderatisme Islam. Hilmymenyatakan: The concept of moderatism in the context of IndonesianIslam has at least the following characteristics; 1) nonviolentideology in propagating Islam; 2) adopting themodern way of life with its all derivatives, includingscience and technology, democracy, human rights andthe like; 3) the use of rational way of thinking; 4)contextual approach in understanding Islam, and; 5) theuse of ijtihâd (intellectual exercises to make a legalopinion in case of the absence of explicit justificationfrom the Qur'ân and Hadith). Those characteristics are,however, can be expanded into several morecharacteristics such as tolerance, harmony andcooperation among different religious groups. ${ }^{5}$

Sementara itu, Muhammad Ali memaknai Islam moderat sebagai those who do not share the hardlinevisions and actions. Dengan pemaknaan ini, ia menyatakanbahwa Islam moderat Indonesia merujuk pada komunitasIslam yang menekankan pada perilaku normal (tawassuth)dalam mengimplementasikan ajaran agama yang merekategakkan; mereka toleran terhadap perbedaan pendapat,menghindari kekerasan, dan memprioritaskan pemikiran dandialog sebagai strateginya. Gagasangagasan semisal Islampribumi, islam rasional, islam progresif, islam transformatif,islam liberal, islam inklusif, islam toleran dan islam pluraldapat dikategorikan sebagai Islam moderat Indonesia.Dari makna diatas, dapat kita pahami bahwa moderatberada pada posisi tengah dan tidak condong kepadagolongan tertentu.Moderat pula dapat diartikan bersikaplunak atau tidak terjerumus kedalam ekstrimisme yang berlebihan. ${ }^{6}$

Wasathiyah (pemahaman moderat) adalah salah satu karakteristik Islam yang tidak dimiliki oleh agama-agamalain. Pemahaman moderat menyeru kepada dakwah Islamyang toleran, menentang segala bentuk pemikiran yangliberal dan radikal.Liberal dalam arti memahami Islamdengan standar hawa nafsu dan murni logika yang cenderungmencari pembenaran yang tidak ilmiah.Islam multikultur adalah kesediaan menerima kelompok lain secara sama sebagai kesatuan,

${ }^{5}$ Prasetiawati.

${ }^{6}$ Prasetiawati.

| RI'AYAH, Vol. 4 No. 01 Januari-Juni 2019 
tanpamempedulikan perbedaan budaya, etnik, jender, bahasa,ataupun agama.

Dalam konteks tersebut,memperbincangkan diskursus Islam multikultural diIndonesia menemukan momentumnya.Sebab, selama iniIslam seringkali ditafsirkan tunggal bukan multikultural.Padahal, di Nusantara realitas Islam multikultur sangatkental, baik secara sosio-historis maupun global-lokal.Secara lokal, Islam di nusantara dibagi menjadi santri,abangan dan priyayi; Islam tradisional dan modern.Secarasosiohistoris, hadirnya Islam di Indonesia tidak bisa lepasdari konteks multikultural sebagaimana dalam sejarahmasuknya Islam ke Nusantara yang dibawa oleh Walisongo.Multikulturalisme merupakan salah satu ajaranTuhan yang sangat bermanfaat bagi umat manusia dalamrangka untuk mencapai kehidupan yang damai di bumi,hanya saja sering tercemari oleh perilaku radikalisme,eksklusivisme, intoleransi dan bahkan fundamentalisme.Hal ini dapat diatasi apabila kita bisa menjadikan iman dantakwa berfungsi dalam kehidupan yang nyata bagi bangsadan negara.

Dapat disimpulkan Islam moderat dan multikulturmerupakan sikap keberagamaan yang mengambil jalantengah dan plural.Sikap keberagamaan seperti ini tidakmenyetujui jalan kekerasan dalam memperjuangkan cita-citaideal Islam dan lebih memilih jalan damai, toleransi,menghargai pluralitas, dan memandang Islam sebagaipembawa perdamaian (rahmat) bagi segenap alam.

\section{Historis Peran Pondok Pesantren}

Nurkholis madjid, metode yang digunakan kiai dalam proses belajar mengajar terlalu mengabaikan aspek kognitif yang berdampak negatif pada output pesantren sendiri. Seorang Kiai menggunakan metode pengajian, yang mana hal ini kurang menekankan aspek kognitif santri.Santri hanya dapat mendengarkan tanpa dapat menanggapi atau mengembangkannya, karena ada konsep su'u adab jika melanggar perintah atau tidak patuh pada perintah seorang kiai. ${ }^{7}$

Belakangan ini sorotan terhadap pesantren terkesan menyimpang dari asasi tradisi pesantren yang akrab dengan pengembangan tradisi keilmuan dan masyarakat. ${ }^{8}$ Bisa jadi, hal ini merupakan isyarat bahwa pesantren memang memiliki fenomena yang harus diungkap. Cukup menarik untuk dicermati dan diperbincangkan dari berbagai sisi. Terlebih pada saat munculnya istilah-istilah era tinggal landas, modernitas, globalisasi, pasar bebas, dan lain sebagainya. ${ }^{9}$

Seiring dengan terjadinya perubahan sosial dan modernisasi di segala bidang, salah satunya modernisasi di bidang pendidikan, sudah barang tentu berpengaruh terhadap keberadaan lembaga pendidikan Islam tradisional seperti pondok pesantren.10Dengan demikian, pesantren

${ }^{7}$ M. Dawam Rahardjo, Pergulatan dunia Pesantren: Membangun dari Bawah. 2009.Jakarta: P3M, hal. 54.

${ }^{8}$ Hasani Ahmad Said, Studi Islam I Kajian Islam Kontemporer, Ed. 1. Cet. 1, (Jakarta: Rajawali Press, 2016), hal. 231.

${ }^{9}$ Kasful Anwar Us, Kepemimpinan Pesantren: Menawarkan Model Kepemimpinan Kolektif dan Responsif, (Jambi: Suthan Thaha Saifuddin Press, 2011), hal. 1.

${ }^{10}$ Ibid.

| RI'AYAH, Vol. 4 No. 01 Januari-Juni 2019 
memiliki daya adaptif terhadap perubahan.Hal ini bisa dipahami dengan menyadari adanya konteks keterikatan antara pesantren dengan masyarakat. ${ }^{11}$

Pesantren terlihat enggan dalam menerima modernisasi, sehingga tercipta apa yang disebut Nurcholis Madjid sebagai kesenjangan antara pesantren dengan dunia luar. Pesantren akan hidup dan mati oleh tingkat kepedulian masyarakatnya. Pesantren tidak lagi identik dengan kelembagaan pendidikan Islam yang khas Jawa, tetapi juga diadopsi oleh wilayah-wilayah lain. ${ }^{12}$

Pesantren merupakan lembaga pendidikan Islam yang dikembangkan oleh masyarakat Indonesia. Karena sebenarnya pesantren merupakan produk budaya masyarakat Indonesia yang sadar sepenuhnya akan pentingnya arti sebuah pendidikan bagi orang pribumi yang tumbuh secara natural. Terlepas dari mana tradisi dan sistem tersebut diadopsi, tidak akan mempengaruhi pola yang unik (khas) dan telah mengakar serta hidup dan berkembang di tengah masyarakat.

Khusus dalam bidang pendidikan, misalnya, pesantren dapat dikatakan kalah bersaing dalam menawarkan suatu model pendidikan kompetitif yang mampu melahirkan santri yang memiliki kompetensi dalam penguasaan ilmu sekaligus skill sehingga dapat menjadi bekal terjun ke dalam kehidupan sosial yang terus mengalami percepatan perubahan akibat modernisasi yang ditopang kecanggihan sains dan teknologi.

Sistem pendidikan di pesantren menggunakan sistem pendidikan tradisional, dengan ciri adanya kebebasan penuh dalam proses pembelajarannya, terjadinya hubungan interaktif antara kyai dan santri. Peserta didik (para santri) dalam menempuh pendidikan di pesantren tidak berorientasi semata mencari ijazah dan gelar, sebagaimana sistem pendidikan di sekolah formal.

Kultur pendidikan diarahkan untuk membangun dan membekali para santri agar hidup sederhana, memiliki idealisme. Dalam sejarahnya, alumni pesantren umumnya tidak bercita-cita untuk menjadi atau menguasai kedudukan (jabatan) di pemerintahan, karena itu mereka juga sulit untuk bisa dikuasai oleh pemerintah. Hal ini juga yang harus di perbaiki, bahwa setiap santri memiliki peran dalam system pemerintahan yang bersih dan baik, ini merupakan salah satu dari peran dan fungsi pengamalan Islam yang moderat di pondok pesantren.

Terkait dengan manajemen pesantren yang merupakan sarana penggunaan sumberdaya yang efektif untuk mencapai sasaran, maka perlu adanya stretegi atau siasat seperti ditegas oleh Mujamil Qomar bahwa manajemen penuh siasat yang diarahkan untuk mencapai sebuah tujuan.

Sebagai seni, manajemen lebih menitikberatkan pada peranan manusia sebagai pelaku manajemen dengan menggunakan pendekatan scientific, tetapi juga professional.Merupakan Lembaga Pendidikan Islam yang paling

\footnotetext{
${ }^{11}$ Musthofa Harun dkk, Khazanah Intelektual Pesantren, Cet. I, (Jakarta: CV. Maloho Jaya Abadi, 2009), hal. 16.

12 Azyumardi Azra, Pendidikan Islam Tradisi dan Modernisasi Menuju MIlenium Baru. (Jakarta: Logos Wacana Ilmu, 2009), hal. 106.
} 
variatif adalah Pesantren, mengingat adanya kebebasan dari kiai pendirinya untuk mewarnai pesantrennya itu penekannya pada kajian tertentu.

Misalnya, ada pesantren ilmu " alat", pesantren fiqih, Pesantren Al Qur'an, Pesantren hadits, atau pesantren tasawuf. Masing-Masing didasarkan pada keahlian kiai-nya. Ditinjau dari segiterbukaan terhadap perubahan-perubahan yang terjadi dari luar, pesantren dapat dibagi dua: Pertama, Pesantren salafi dan kedua pesantren Pesantren khalafi. Pesantern salafi bersifat kenservatif sedangan khalafi bersifat adaptif. Adaptasi dilakukukan terhadap perubahan dan pengembangan pendidikan yang merupakan akibat dari tuntutan perkembangan sains dan teknologi. ${ }^{13}$

Pesantren salafi pada umumnya para santri kuat dalam tela'ah kitab-kitab warisan ulama' klasik. Mereka menguasai teori Bahasa Arab secara baik, namun kurang menekankan aspek praktis dari pemanfa'atan bahasa sebagai alat komunikasi verbal.Sebaliknya, sistem yang kedua khalafi pada umumnya, kurang dalam penguasaan kitab klasik, namun mereka telah membiasakan Bahasa Arab dan Bahasa Inggris sebagai bahasa pengantar keseharian.

Perbedaan pesantren tradisional dengan pesantren modern dapat diidenfifikasi dari perpespektif manajerialnnya.Pesantren modern telah dikelola secara rapi dan sistematis dengan mengikuti kaidah-kaidah manajerial yang umum.Sementara itu, pesantren tradisional berjalan secara alami tanpa berupaya mengelola secara efektif. ${ }^{14}$

Masa Depan pesantren sangat ditentukan oleh faktor manajerial. Pesantren kecil akan berkembang secara signifikan manakala dikelola secara profesioanal. Dengan pengelolaan yang sama pesantren yang mudah besar akan bertambah besar. Sebaliknya pesantren yang maju akan mengalami kemunduran manakala manajemennya tidak terurus dengan baik. Jika pesantren mengabaikan manajemen, pesantren kecil akan gulung tikar dalam mengahadapi multideimensi. Pola-Pola kepemimpinan kiai di pesantren yang selama ini kurang kondusif menghadapi tantangantantangan moderenisasi bahkan perlu diubah menjadi pola-pola kepemimpinan yang lebih responsif terhadap tuntutan kemajuan zaman. Pola tersebut haruslah mengarah pada kegiatan yang melibatkan lebih banyak orang lain lagi dalam jajaran kepemimpinan, untuk bersama-sama menjalankan roda organisasi pesantren menuju kondisi yang maju dan mapan, baik dari sisi kelembagaan, sistem pendidikan, proses pembelajaran, maupun kualitas santri.

Kasus yang ada pada beberapa pesantren telah membuktikan bahwa peran serta kiai dalam mengelola, mengembangkan dan menata pesantren sehingga dapat muncul sebagai sebuah lembaga yang dapat dijadikan pendidikan alternatif memiliki peranan yang sangat besar, sebab tidak jarang pesantren akan tutup dikarenakan oleh beberapa hal yakni: pertama kharismatik kiai di pesantren tersebut telah luntur bersama meninggalnya kiai utama sebagai pendirinya, Kedua tidak adanya pengganti yang dapat meneruskan estapet kepemimpinanya, Ketiga kesibukan kiai yang dapat mengabaikan proses

${ }^{13} \mathrm{Ibid}$.

${ }^{14}$ Mujamil Qomar, Manajemen Lembaga Pendidikan Islam, (Jakarta: Erlangga, 2007), hal. 11. 
belajar mengajar, Keempat kurang seimbangnya tuntutan kebutuhan belajar santri dengan pelayanan yang diberikan oleh pesantren tersebut.

Menurut Nurcholis Madjid ada beberapa kerugian kepemimpinan karismatik antara lain; (1) Ketidakpastian dalam perkembangan pesantren karena semua hal tergantung kepada keputusan pribadi kiai. (2) Keadaan kurang mendukung tenaga-tenaga pembantu untuk pengembangan yang belum diterima figur kepemimpinan yang ada. (3) Pola pergantian kepemimpinan berlangsung secara tiba-tiba dan tidak direncanakan sehingga lebih banyak ditandai oleh sebab-sebab alami seperti meninggalnya pemimpin secara mendadak. (4) Terjadinya pembauran dalam tingkat pemimpin di pesantren antara lokal regional dan nasional. ${ }^{15}$

\section{Peran Pengelolaan Pondok Pesantren}

Pondok Pesantren sangat berperan mengajarkan ajaran Islam yang moderat untuk menanggulangi masuknyapaham radikal dan fundamental di kalangan generasi muda.Islam moderat adalah nilai-nilai islam yang dibangun atasdasar pola pikir yang lurus dan pertengahan (i"tidal danwasath). Menurut Yusuf al-Qardhawi, wasathiyah (moderat) merupakan salah satu karakteristik yang tidak dimilikiideologi lain. Dalam al-Qur'an dijelaskan:Artinya: Dan demikianlah Kami jadikan kalian sebagaiumat pertengahan, agar kamu menjadi saksi atas(perbuatan) manusia dan agar Rasul (Muhammad)menjadi saksi atas (perbuatan) kamu. (QS. AlBaqarah:143).

Salah satu bentuk lembaga keagamaan di Indonesia yang mendapat sorotan setelah terjadi aksi radikal adalah pesantren.Sejak terungkapnya pelaku pengeboman yang melibatkan alumni pesantren al-Islam di Lamongan, radikalisme sering kali dikaitkan dengan pendidikan agama di pesantren.Fenomena radikalisme pesantren sesungguhnya sesuatu yang aneh.Pesantren sebagai institusi keagamaan sebenarnya tidak didirikan untuk melahirkan radikalisme.Pesantren bertugas untuk mencetak kaderkader ulama yang berpengetahuan luas (tafaqquh fi al-din).

Upaya pencegahan radikalisme agama tidak boleh setengahsetengah. Sebagai pendidik, harus mengoptimalkan gerakan radikalisasi mulai dari lingkungan rumah, sekolah, dan pergaulan peserta didik. Saat ini banyak lembaga pendidikan yang modern dan liberal sehingga mudah dimasuki paham-paham radikal. Oleh karena itu, jika generasi muda mendapat pendidikan agama dan umum yang baik, secara otomatis paham radikal akan terbendung dengan sendirinya. ${ }^{16}$

Pengelolaan pondok pesantren dalam pengembangan pendidikan agama Islam, terdapat dua kata bantu yang terdapat dalam al-Qur'an untuk mempelajari pengorganisasian ini. Kata tersebut adalah (Shaff) dan (ummat). Peneliti mengidentikkan kata (shaff) ini dengan organisasi. Jadi organisasi menurut analisis kata ini adalah suatu perkumpulan atau jamaah yang mempunyai sistem yang teratur dan tertib untuk mencapai tujuan bersama. Dalam surah al-Shaff ayat 4 dikemukakan:Sesungguhnya Allah menyukai orang

${ }^{15}$ Azyumardi Azra, Op. Cit, hal. 108.

${ }^{16}$ Eka Prasetiawati, "Menanamkan Islam Moderat Untuk Menanggulangi Radikalisme Di Indonesia," Fikri: Jurnal Kajian Agama, Sosial Dan Budaya 2, no. 2 (27 Desember 2017): 523-70, https://doi.org/10.25217/jf.v2i2.152. 
yang berperang dijalan-Nya dalam barisan yang teratur seakan-akan mereka seperti suatu bangunan yang tersusun kokoh.

Maksud dari shaff disitu menurut al-Qurtubi adalah menyuruh masuk dalam sebuah barisan (organisasi) supaya terdapat keteraturan untuk mencapai tujuan. ${ }^{17}$ Suatu pekerjaan apabila dilakukan dengan teratur dan terarah, maka hasilnya juga akan baik. Maka dalam suatu organisasi yang baik, proses juga dilakukan secara terarah dan teratur.

Perlunya membangun pendidikan di Pondok Pesantren dengan pengelolaan organisasi yang baik, untuk pengembangan pendidikan Islam yang moderat lebih baik.Kawasan pengembangan mencakup banyak variasi teknologi yang digunakan dalam pembelajaran, hal ini menjadi tantangan santri zaman sekarang, bagaimana teknologi harus bisa menjadi alat untuk membangun pendidikan Islam yang lebih ramah dan santun bukan menjadi media yang memprovokasi. ${ }^{18}$ Pentingnya pendidikan moral, akidah, dan akhlak harus didukung oleh kemauan, kerjasama yang kompak dan usaha yang sungguh-sungguh dari keluarga/rumah tangga, sekolah dan masyarakat. ${ }^{19}$

Karena pendidikan Islam dalam konsep moderat juga berarti usaha sadar untuk menyiapkan santri dalam meyakini, memahami, menghayati dan mengamalkan Islam melalui kegiatan bimbingan, pengarahan atau. latihan dengan memperhatikan tuntutan untuk menghormati agama lain dalam hubungan kerukunan antar umat beragama dalam masyarakat untuk mewujudkan kesatuan nasional. ${ }^{20}$

Tujuan moderasi pendidikan Islam itu adalah untuk membentuk manusia yang bertanggung jawab terhadap dirinya dan masyarakat guna tercapainya kebahagiaan dunia dan akhirat.Dengan demikian, tujuan akhir dari pendidikan agama Islam itu karena semata-mata untuk beribadah kepada Allah SWT. Dengan cara berusaha melaksanakan semua perintahNya dan meningglkan larangan-Nya. ${ }^{21}$

Permasalahan seputar pengembangan model pendidikan pondok pesantren dalam hubungannya dengan peningkatan kualitas sumberdaya manusia merupakan isu aktual dalam arus perbincangan kepesantrenan kontemporer. Maraknya perbincangan mengenai isu tersebut tidak bisa dilepaskan dari realitas empirik keberadaan pesantren dewasa ini yang dinilai kurang mampu mengoptimalisasi potensi yang dimilikinya. Setidaknya terdapat dua potensi besar yang dimiliki pesantren yaitu potensi pendidikan dan pengembangan masyarakat.Hal ini tentunya bisa disikapi dengan pengamalan pendidikan Islam yang baik di setiap pondok pesantren.

\footnotetext{
${ }^{17}$ Al-Qurtubi, Samsyu al-Din, Jami' al-Bayan li al-Ahkam al-Qur'an, juz 1, Mauqi'u al-Tafsir: Dalam Software Maktabah Samilah, 2005.

${ }^{18}$ Deni Darmawan, Inovasi Pendidikan: Pendekatan Praktik Teknologi Multimedia dan PembelajaranOnline, (Bandung: Remaja Rosdakarya, 2012), hal. 12.

${ }^{19}$ Merle J. Schwartz, Effective Character Education, (Newyork: McGraw-Hill, 2008), hal. 7.

${ }^{20}$ Akmal Hawi, Kompetensi Guru Pendidikan Agama Islam, (Jakarta: Raja Grafindo Persada, 2014), hal. 19.

${ }^{21}$ Ibid., hal. 21.
} 


\section{Kesimpulan}

Islam moderat Indonesia merujuk pada komunitasIslam yang menekankan pada perilaku normal (tawassuth)dalam mengimplementasikan ajaran agama yang merekategakkan; mereka toleran terhadap perbedaan pendapat,menghindari kekerasan, dan memprioritaskan pemikiran dandialog sebagai strateginya. Gagasan-gagasan semisal Islampribumi, islam rasional, islam progresif, islam transformatif,islam liberal, islam inklusif, islam toleran dan islam pluraldapat dikategorikan sebagai Islam moderat Indonesia.

Wasathiyah (pemahaman moderat) adalah salah satu karakteristik Islam yang tidak dimiliki oleh agama-agamalain. Pemahaman moderat menyeru kepada dakwah Islamyang toleran, menentang segala bentuk pemikiran yangliberal dan radikal.Liberal dalam arti memahami Islamdengan standar hawa nafsu dan murni logika yang cenderungmencari pembenaran yang tidak ilmiah.Islam multikultur adalah kesediaan menerima kelompok lain secara sama sebagai kesatuan, tanpamempedulikan perbedaan budaya, etnik, jender, bahasa,ataupun agama.

Peran pengelolaan pondok pesantren menolak segala bentuk tindakan radikalisme dan ekstrimisme, aksi terror yang merusak sendi-sendi kerukunan dan kedamaian ummat manusia. Dalam tulisan ini, penulis ingin menjelaskan tentang bagaimana peran pondok pesantren dalam kegiatan sehari-hari di pondok pesantren, untuk mengembangkan Islam yang moderat, mulai proses belajar mengajar di kelas, kegiatan ekstra kurikuler dan pengabdian di lingkungan masyarakat sekitar pondok pesantren. Karena pondok pesantren adalah lembaga yang menggaungkan dan mengajak masyarakat dengan Islam yang moderat Islam rahmatallil'alamin.

\section{Referensi}

Akmal Hawi, Kompetensi Guru Pendidikan Agama Islam, (Jakarta: Raja Grafindo Persada, 2014).

Al-Qurtubi, Samsyu al-Din, Jami' al-Bayan li al-Ahkam al-Qur'an, juz 1, Mauqi'u al-Tafsir: Dalam Software Maktabah Samilah.

Azyumardi Azra, Pendidikan Islam Tradisi dan Modernisasi Menuju MIlenium Baru. (Jakarta: Logos Wacana Ilmu, 2009).

Deni Darmawan, Inovasi Pendidikan: Pendekatan Praktik Teknologi Multimedia dan PembelajaranOnline, (Bandung: Remaja Rosdakarya, 2012).

Eka Prasetiawati, "Menanamkan Islam Moderat Untuk Menanggulangi Radikalisme Di Indonesia," Fikri : Jurnal Kajian Agama, Sosial Dan Budaya 2, no. 2 (27 Desember 2017): 523-70, https:// doi.org/10.25217/jf.v2i2.152.

Hasani Ahmad Said, Studi Islam I Kajian Islam Kontemporer, Ed. 1. Cet. 1, (Jakarta: Rajawali Press, 2016). 
Sumarto dan Emmi Kholilah Harahap Mengembangkan Moderasi Pendidikan...

Kasful Anwar Us, Kepemimpinan Pesantren: Menawarkan Model Kepemimpinan Kolektif dan Responsif, (Jambi: Suthan Thaha Saifuddin Press, 2011).

M. Dawam Rahardjo, Pergulatan dunia Pesantren: Membangun dari Bawah. 2009.Jakarta: P3M.

Merle J. Schwartz, Effective Character Education, (Newyork: McGraw-Hill, 2008).

Mohammad Muchlis Solichin, "PENDIDIKAN ISLAM MODERAT DALAM BINGKAI KEARIFAN LOKAL," Jurnal MUDARRISUNA: Media Kajian Pendidikan Agama Islam 8, no. 1 (20 Juli 2018): 174-94, https:// doi.org/10.22373/jm.v8i1.2950.

Mujamil Qomar, Manajemen Lembaga Pendidikan Islam, (Jakarta: Erlangga, 2007), hal. 11.

Musthofa Harun dkk, Khazanah Intelektual Pesantren, Cet. I, (Jakarta: CV. Maloho Jaya Abadi, 2009), hal. 16. 